\title{
LIPOHAEMOARTHROSIS OF THE LATERAL POSTERIOR FEMORAL RECESS
}

\author{
Kho J.1, Perry A. ${ }^{2}$, Beale D.2, James S.L. ', Botchu R.'
}

ne of the common causes of lipohaemarthrosis (LPH) is presence of intra-articular fractures. The imaging features of LPH are typically seen in the suprapatellar pouch of the knee. We report a case of LPH with a three layer fluid-fluid level in the lateral posterior femoral recess of the knee, posterior to the lateral femoral condyle.

1 - Department of Musculoskeletal Radiology. Royal Orthopaedic Hospital. Birmingham, UK. 2 - Heath Lodge Clinic. Knowle, UK.

Keywords: lipohaemoarthrosis, knee, posterior recess.

Corresponding author: Rajesh Botchu, e-mail: drbrajesh@yahoo.com

For citation: Kho J., Perry A., Beale D., James S.L., Botchu R. Lipohaemoarthrosis of the lateral posterior femoral recess. REJR 2020; 1O(2):291-294. DOI:10.21569/2222-7415-202010-2-291-294.

Received: $\quad 20.04 .20 \quad$ Accepted: $\quad 19.06 .20$

\section{АИПОГЕМАРТРОЗ ААТЕРААЬНОГО ЗААНЕГО ФЕМОРААЬНОГО КАРМАНА}

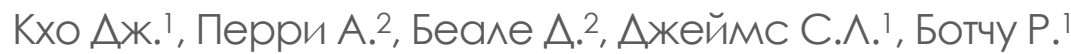

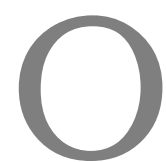

дной из распространенных причин мипогемартроза является наличие внутрисуставных переломов. Типичные признаки мипогемартроза обычно видны в области супрапатемлярной сумки коленного сустава. Мы представляем клинический случай мипогемартроза с трехслойным уровнем жидкостьжидкость в боковом заднем феморальном кармане коленного сустава, кзади от бокового мыщелка бедренной кости.

КАючевые слова: мипогемартроз, коленный сустав, задний карман.

1 - Отделение костномышечной радиологии. Королевская ортопедическая больница. Бирмингем, Великобритания. 2 - Кминика "Heath Lodge".

Ноуц, Великобритания.

Контактный автор: Ботчу P., e-mail: drbrajesh@yahoo.com

Для иитирования: Кхо Дж., Перри А., Беале Д., Джеймс С.А., Ботчу Р. Аипогемартроз латерального заднего феморального кармана. REJR 2020; 10(2):291-294. DOI:10.21569/2222-7415-2020-10-2-291-294..
Статья получена:
20.04.20
Статья принята:
19.06.20

I

ntroduction.

One of the common causes of lipohaemarthrosis (LPH) is presence of an intraarticular fractures $[1,2]$. These can be seen in a variety of joints with knee being the most common [2-4]. The imaging features of LPH are typically seen in the suprapatellar pouch of the knee. We report a case of LPH with a three layer fluid-fluid level in the lateral posterior femoral recess of the knee, posterior to the lateral femoral condyle.

\section{Case report.}

18 year old female presented with an acute right knee injury following a skiing accident. There was no relevant past medical history of note. She had MRI of the right knee which demonstrated a minimally displaced intraarticular fracture of the proximal tibia with a minimally displaced fracture of the avulsion fracture of the tibial spine at the tibial attachment of the ACL. There was a large knee joint effusion with a fluid-fluid level in the suprapatellar pouch and a further three layered LPH in the posterior recess 


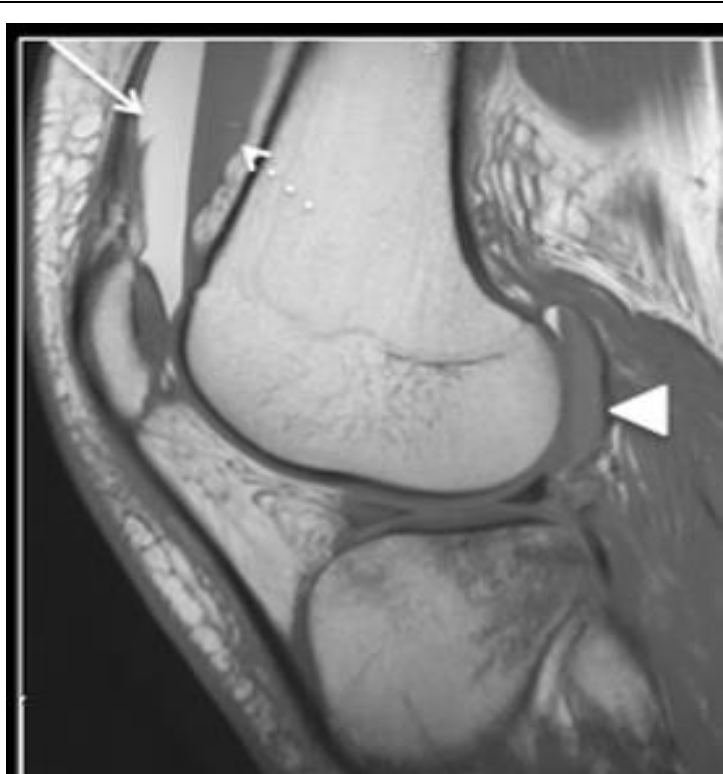

Fig. 1 a (Рис. 1 a)

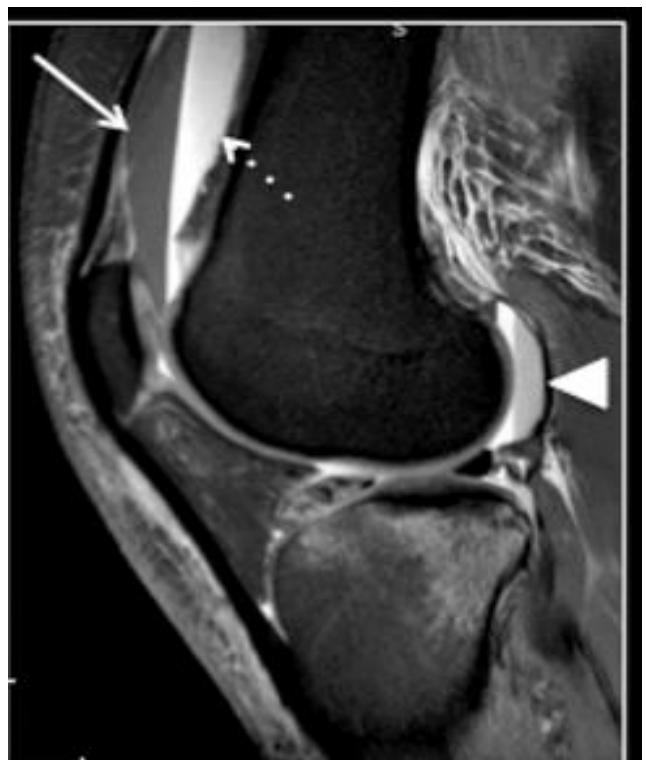

Fig. 1 b (Рис. 1 б)

\section{Fig. 1. MRI. Knee joint.}

Sagittal T1(a) and PDFS(b) showing a fluid fluid level in the suprapatellar pouch (fat layer (arrow), serum (dashed arrow)) and three layer of LPH (arrow head - most dependent layer with red blood cells, white blood cells and hemoglobin) in the posterior recess of the knee.

\section{Рис. 1. МРТ. Коленный сустав.}

Сагиттальные T1 (а) и PDFS (б) изображения, демонстрирующие уровень жидкости в супрапателяяной сумке (жировой слой (стрелка), сыворотка (пунктирная стрелка)) и три слоя кипогемартроза (острие стрелки - самый зависимый слой с эритроцитами, цейкоцитами и гемоглобином) в заднем кармане коленного сустава.

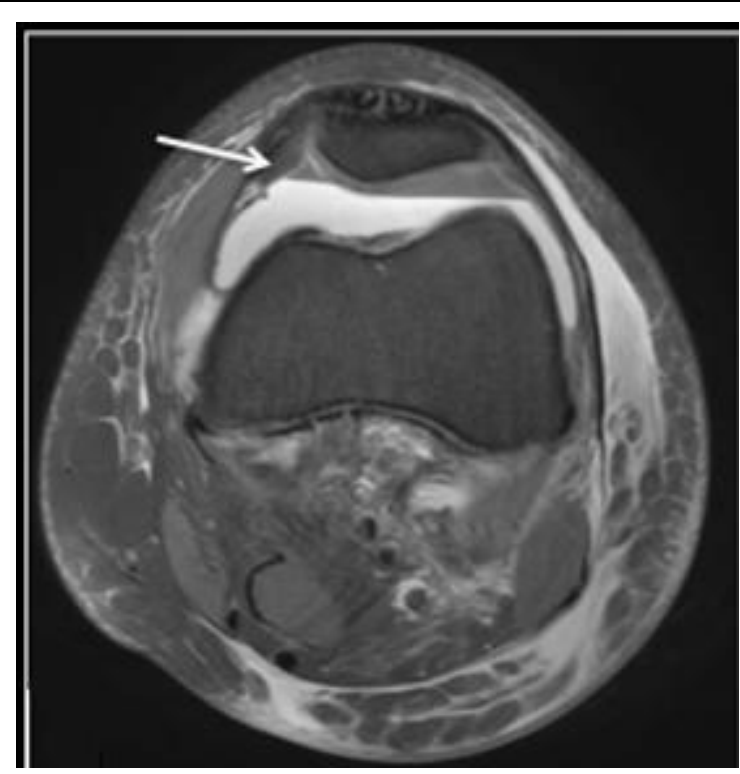

Fig. 2 a (Рис. 2 a)

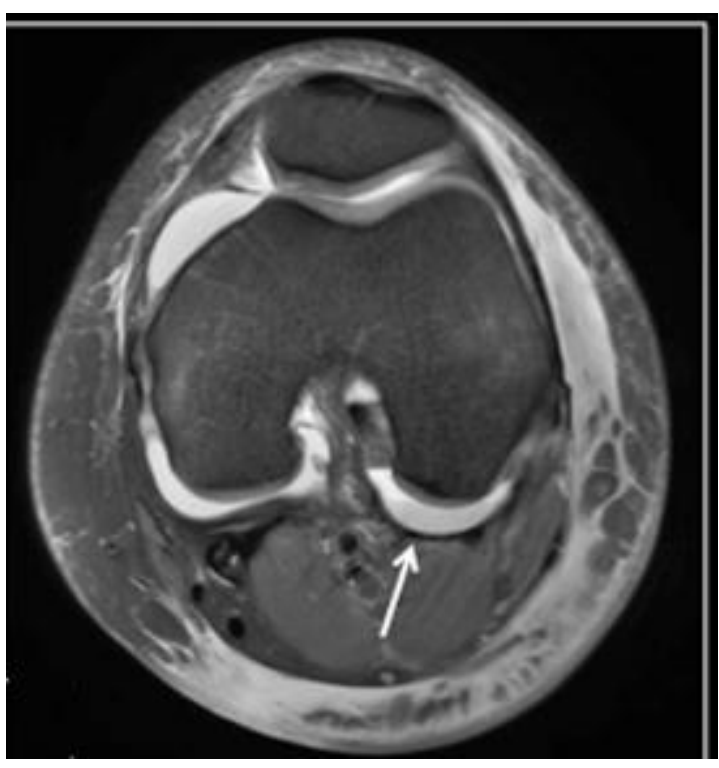

Fig. 2 b (Рис. 2 б)

\section{Fig. 2. MRI. Knee joint.}

Axial PDFS showing fluid fluid levels in the suprapatellar pouch (arrow (a)) and three layer of LPH posterior to the lateral femoral condyle (arrow(b)).

\section{Рис. 2. МРТ. Коленный сустав.}

На аксиальных PDFS изображениях показаны уровни жидкости в супрапателяярной сумке (стрелка (а)) и три слоя кипогемартроза позади матерального мыщелка бедренной кости (стрелка (б)). 


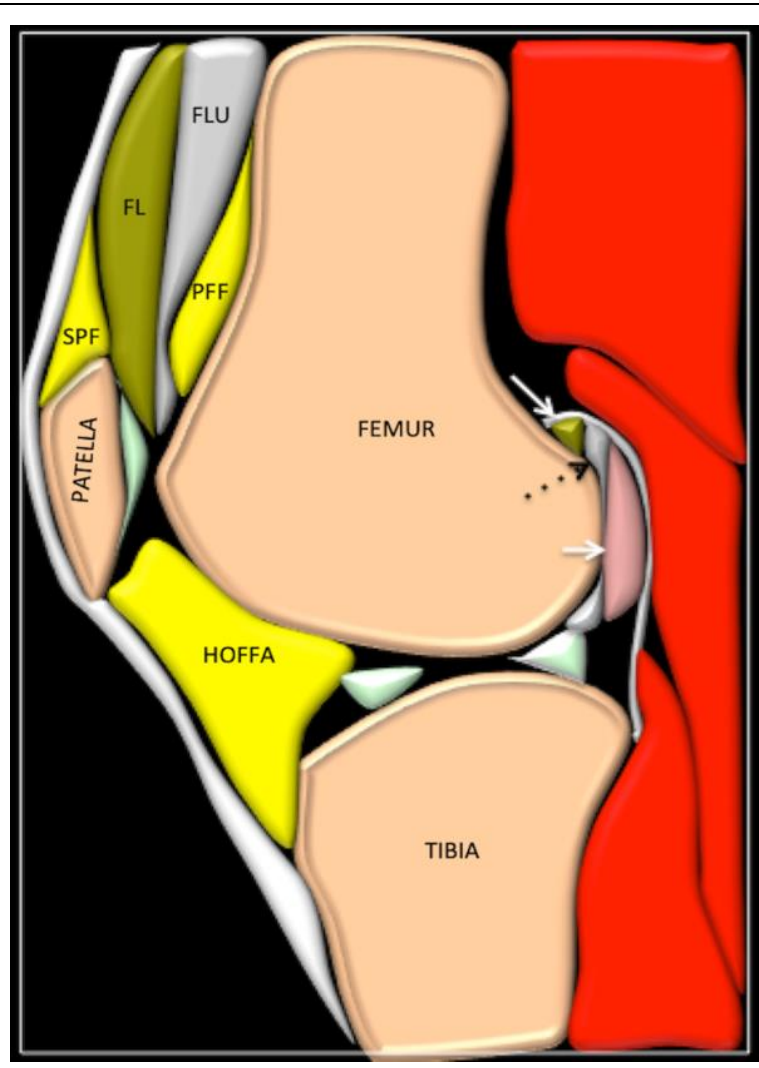

Рис. 3 (Fig. 3)

\section{Fig. 3. Scheme. Knee joint.}

Animation of the sagittal of the knee showing fluid levels of LPH (arrow - fat layer, black dashed arrow - serum, short arrow - dependent layer of blood cells and hemoglobin). FL (fat layer), FLU (serum), PFF (prefemoral fat pad), SPF (suprapatellar fat pad).

\section{Рис. 3. Схема. Коленный сустав.}

Анимация сагиттального среза коленного сустава, показывающая уровень жидкости при мипогемартрозе (стрелка -жировой слой, черная пунктирная стрелка - сыворотка, короткая стрелка - зависимый слой клеток крови и гемогмобина). FL (жировой слой), FLU (сыворотка), PFF (префеморальное жировое тело), SPF (наднадколенниковое жировое тело).

behind the lateral femoral condyle (Fig. 1-4). The orthopedic surgeon managed operatively to repair the ACL avulsion injury.

\section{Discussion.}

LPH of the knee is a common finding in patients following knee trauma. This is seen in approximately $40 \%$ of patients with intra-articular fractures [1]. However $100 \%$ of those with LPH have intra-articular fractures [1]. This is due to extravasation of marrow fat into the joint through an intra-articular fracture. LPH has three layers: the floating fat forms - the most superficial layer, the serum forms - the second layer and the most dependent layer consists of red and white blood cells $[2,5,6] . \mathrm{LPH}$ can be diagnosed on lateral radiographs, ultrasound, CT and MRI [2, 5-8]. The MR features of LPH are dependent on the composition of each layer. The most superficial layer has signal features of fat with high signal on T1 and T2 and low signal on fat suppression sequences. The second layer is low on T1 and high on T2. The bottom layer of LPH is of isointense signal to muscle on T1 and higher than muscle signal on T2. LPH can be seen in any intracapsular region, though the suprapatellar pouch is by far the most common [2]. Other sites occasionally seen include between superficial and deep parts of the MCL, the infrapatellar recess. LPH may infrequently be seen within a Baker's cyst [2].

In this report, we describe a case of fluidfluid level (two layer) within the suprapatellar pouch and classic three layer fluid level in the posterior recess, posterior to the lateral femoral condyle. There was an associated avulsion fracture of the tibial spine at the tibial attachment of the ACL as well as a minimally displaced intraarticular fracture of the proximal tibia. Anterior translation of tibia of greater than $5 \mathrm{~mm}$ is associated with an ACL tear with a specificity of $80-99 \%$ and sensitivity of $56-86 \%$ [9-11]. There was no anterior translation of tibia in relation to femur in our case. This could be due to hinging of the tibial spine avulsion fracture with the proximal tibia. The posterior recess, behind the lateral femoral condyle is normally obliterated by the posterior aspect of the lateral femoral condyle in patients with anterior translation of the tibia in relation to the femur. However in our case the posterior recess was formed as a sequale of a pivot shift pattern of injury but not obliterated, as there was no tibial translation. We postulate that this allowed the LPH to form in this anatomic recess.

LPH does not occur immediately after injury. Previous in vitro and cadaveric studies have showed that the three layers form from a blood-fat mixture at 30 minutes -3 hours $[5,8]$. The presence of the three layer appearance of LPH only in the lateral aspect of the posterior recess in our patient suggests that this portion of the posterior recess has been separated from the rest of the knee for at least 30 minutes. The posterior femoral recess has previously been described as a continuous synovial recess between the posterior aspect of the medial and lateral femoral condyles and posterior capsule, with $9 \%$ of post traumatic effusions occurring in this location [12, 13]. One possible explanation for the apparent sequestration of LPH in the lateral aspect of the posterior femoral recess in our patients is that the PCL acts as a boundary between this portion of the recess and the rest of the knee.

\section{Conclusion.}

LPH is a classic radiological finding with in 


\section{RUSSIAN ELECTRONIC JOURNAL OF RADIOLOGY}

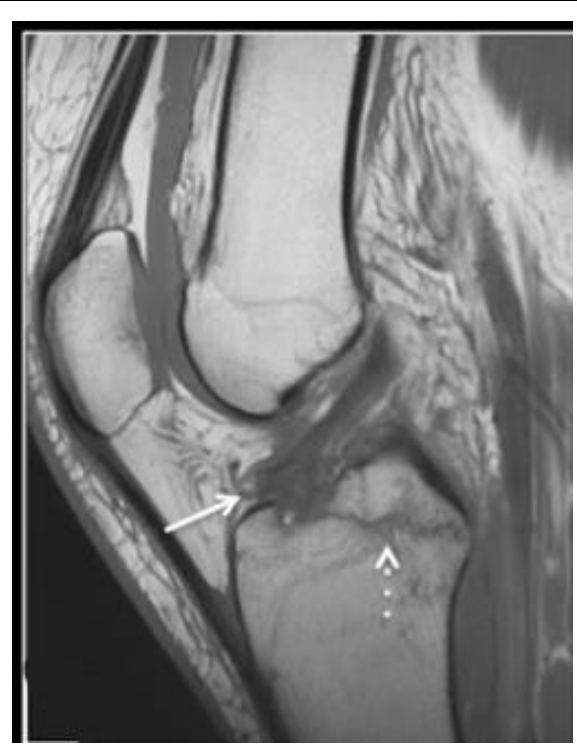

Fig. 4 a (Рис. 4 a)

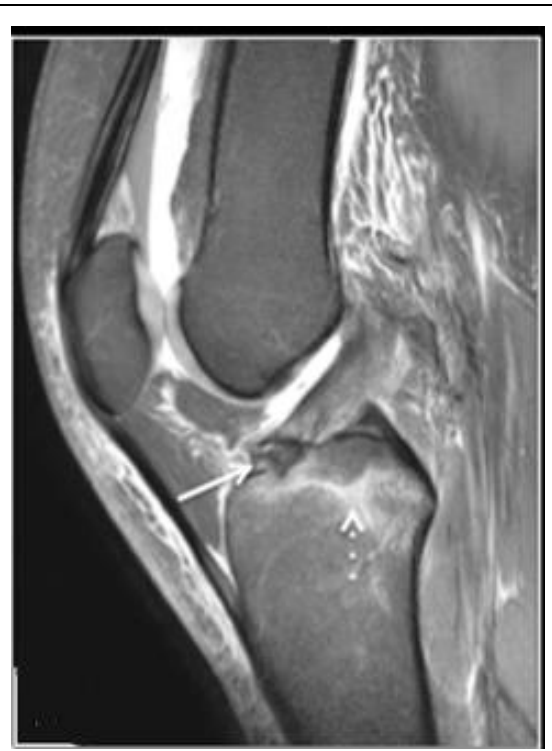

Fig. 4 b (Pис. 4 б)

\section{Fig. 4. MRI. Knee joint.}

Sagittal T1 (a) and PDFS (b) showing avulsion fracture of the tibial spine at the tibial attachment of ACL (arrow) and fracture of the proximal tibia (dashed arrow).

\section{Рис. 4. МРТ. Коленный сустав.}

Сагиттальные T1 (a) и PDFS (б) изображения, показывающие отрывной перелом межмыщелкового возвышения большеберцовой кости в области прикреплении передней крестообразной связки к большеберцовой кости (стрелка) и перелом проксимального отдела большеберцовой кости (пунктирная стрелка).

tra-capsular fractures. This is the first reported case of LPH in the lateral aspect of the posterior femoral recess of the knee.

\section{References:}

1. Lee JH, Weissman BN, Nikpoor N, Aliabadi P, Sosman JL. Lipohemarthrosis of the knee: a review of recent experiences. Radiology. 1989;173(1):189-191 doi:10.1148/radiology.173.1.2781006

2. Davis DL, Vachhani P. Traumatic Extra-capsular and Intracapsular Floating Fat: Fat-fluid Levels of the Knee Revisited. J Clin Imaging Sci. 2015;5. doi:10.4103/2156-7514.170729

3. Peirce CB, Eaglesham DC. Traumatic Lipo-Hemarthrosis of the Knee. Radiology. 1942;39(6):655-662. doi:10.1148/39.6.655

4. Yousefzadeh DK, Jackson JH. Lipohemarthrosis of the Elbow Joint. Radiology. 1978;128(3):643-645. doi:10.1148/128.3.643 5. Ryu KN, Jaovisidha S, De Maeseneer M, Jacobson J, Sartoris DJ, Resnick D. Evolving stages of lipohemarthrosis of the knee. Sequential magnetic resonance imaging findings in cadavers with clinical correlation. Invest Radiol. 1997;32(1):7-11. doi:10.1097/00004424-199701000-00002

6. Thawait SK, Vossen JA, Muro GJ, Karol I. MRI illustration of traumatic lipohemarthrosis of the wrist joint due to a scaphoid fracture. Radiol Case Rep. 2012;7(3):688. doi: $10.2484 /$ rcr.v7i3.688

7. Costa DN, Cavalcanti CFA, Sernik RA. Sonographic and CT Findings in Lipohemarthrosis. Am $J$ Roentgenol. 2007;188(4):W389-W389. doi:10.2214/AJR.06.0975

\section{Conflict of interest.}

We declare that are no financial interest and no conflict of interest exists.

8. Bianchi S, Zwass A, Abdelwahab IF, Ricci G, Rettagliata F, Olivieri M. Sonographic evaluation of lipohemarthrosis: clinical and in vitro study. J Ultrasound Med. 1995;14(4):279-282. doi:10.7863/jum.1995.14.4.279

9. Kalegowda A, Ahmed J, Mehetri G. Anterior Translation of the Tibia at MR Imaging as a Predictor of Degree of Anterior Cruciate Ligament Tear. 2018;7:5.

10. Vahey TN, Hunt JE, Shelbourne KD. Anterior translocation of the tibia at MR imaging: a secondary sign of anterior cruciate ligament tear. Radiology. 1993;187(3):817-819. doi:10.1148/radiology.187.3.8497637

11. Chan WP, Peterfy C, Fritz RC, Genant HK. MR diagnosis of complete tears of the anterior cruciate ligament of the knee: importance of anterior subluxation of the tibia. AJR Am J Roentgenol. 1994;162(2):355-360. doi:10.2214/ajr.162.2.8310927 12. Fenn S, Datir A, Saifuddin A. Synovial recesses of the knee: $M R$ imaging review of anatomical and pathological features. Skeletal Radiol. 2008;38:317-328. doi:10.1007/s00256-0080570-0

13. Kaneko K, De Mouy EH, Robinson AE. Distribution of joint effusion in patients with traumatic knee joint disorders: MRI assessment. Clin Imaging. 1993;17(3):176-178. doi:10.1016/0899-7071(93)90104-u. 